\title{
Population and feeding responses of the corallivorous pufferfish Arothron meleagris to coral mortality in the eastern Pacific
}

\author{
Héctor M. Guzmán, D. Ross Robertson* \\ Smithsonian Tropical Research Institute (Panama) \\ APO, Miami, Florida 34002-0011, USA
}

\begin{abstract}
Arothron meleagris occurs at densities ranging from 0 to 320 fish ha ${ }^{-1}$ of live coral on eastern Pacific coral reefs of Costa Rica, Panamá, Colombia and the Galápagos Islands. On reefs in Panamá and Costa Rica, over $50 \%$ of corals died during the 1982-83 El Nin̄o event and $40 \%$ of remaining corals at Caño Island, Costa Rica, died during red tides in 1985. The population density of $A$. meleagris is not related to coral density on different reefs and fish densities did not change in a consistent manner following the coral mortalities. Diets and feeding preferences of $A$. meleagris at different sites are not related in a consistent way to the abundance of various corals or to changes in coral abundances following coral mortalities. At Caño Island A. meleagris prefers Porites lobata over the less abundant Pocillopora damicornis. At Uva Island, Panamá, where $P$. damicornis is the more abundant species, $A$. meleagris does not prefer either coral. The relationship between the availability and consumption of the uncommon coral Psammocora stellata also differs among localities. Changes in this fish's diet following the mass coral mortalities varied among sites. At Caño Island fish switched first to coralline algae and then to corals. Fish do grow when experimentally fed only coralline algae, but grow better when fed corals. The ability of the puffer to switch diets and maintain its populations following coral mortality may affect the recovery of coral populations. Even when uncommon, the puffer may have an impact on rare corals.
\end{abstract}

\section{INTRODUCTION}

During the 1982-83 El Niño event, coral reefs in many areas of the tropical eastern Pacific, including the Galápagos, Colombia, Panamá and Costa Rica, suffered heavy coral mortality, with overall coral death exceeding 50\% at many sites (Glynn 1984, Prahl 1985, Robinson 1985, Guzmán et al. 1987, Glynn et al. in press). The corals at Caño Island, Costa Rica, suffered a second mass mortality (overall $41 \%$ reduction in cover) due to severe red tides during June to September, 1985 (Guzmán 1986). Concurrent red tides produced less mortality at. Uva reef, Panamá (Guzmán et al. unpubl.).

The Indo-Pacific pufferfish Arothron meleagris (Bloch \& Schneider) occurs throughout the eastern Pacific on both mainland reefs and all offshore islands (Thomson et al. 1979). Its diet usually consists almost entirely of live corals (Hiatt \& Strasburg 1960, Glynn et al. 1972, Hobson 1974). Since changes in the reef fish communities

- Order of authorship is alphabetical and their impact on surviving corals might be expected following extensive coral mortality (cf. Sano et al. 1984, Williams 1986), we investigated the relationship between availability of coral and the density of $A$. meleagris on coral reefs before and after the mass coral mortality at several eastern Pacific localities. We also examined the $\operatorname{diet}$ of $A$. meleagris at those sites following the coral mortality. We relate this information on its diet to (a) the results of experiments on prey choice in Costa Rica and Panamá, and (b) the results of experiments that compare the growth of $A$. meleagris on coral and non-coral diets. Finally, we consider the possible effects of feeding preferences of $A$. meleagris on the recovery of coral populations in Costa Rica.

\section{METHODS}

Study sites. Field observations were carried out on coral reefs at 6 localities in the eastern Pacific (Fig. 1): (1) Caño and (2) Cocos Islands in Costa Rica (January and August 1985, September to November 1986, 


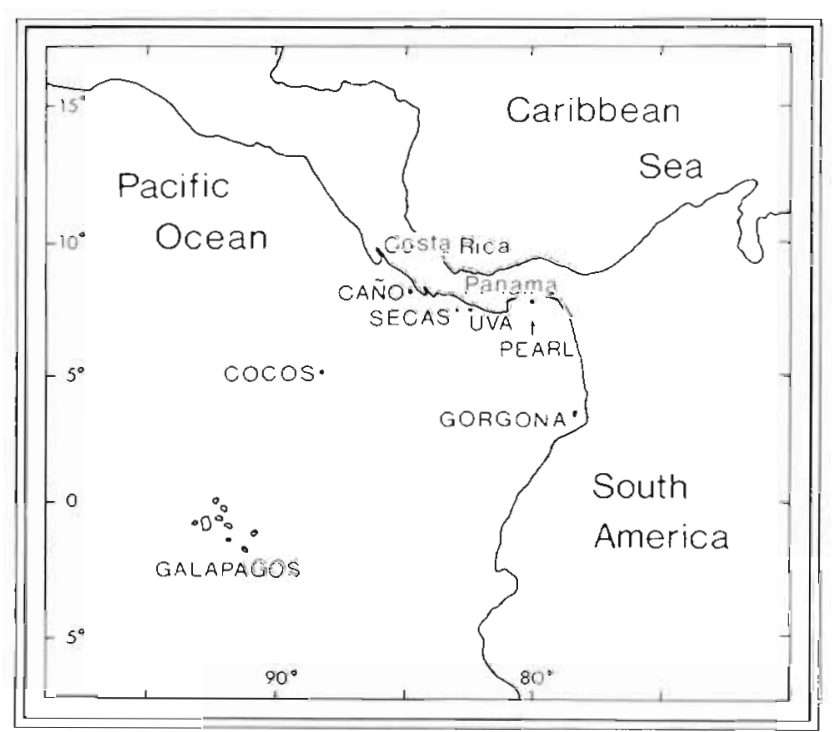

Fig. 1. Coral reef sites studied in the eastern Pacific

August 1987; and December 1986, 1987 respectively); (3) Uva and Secas Islands (August 1986, March 1988) in the Gulf of Chiriquí, and (4) Señorita, Saboga, Contadora, Pacheca and Chapera Islands (June 1987) in the Pearl Archipelago, Gulf of Panamá; (5) Gorgona Island in Colombia (December 1987, July 1988); and (6) Santa Cruz Island in the Galápagos Archipelago (November 1986). General descriptions of the structure and biology of eastern Pacific coral reefs are available for Costa Rica (e.g. Bakus 1975, Guzmán 1986), Panamá (e.g. Glynn et al. 1972, Glynn 1976) and Galápagos (e.g. Glynn \& Wellington 1983).

Many eastern Pacific reefs are made up of a shallow (1 to $8 \mathrm{~m}$ depth) mass of intermeshing pocilloporid colonies, primarily Pocillopora damicornis (Glynn \& Wellington 1983), which is bordered in deeper areas (8 to $12 \mathrm{~m}$ ) by mixed, less dense stands of pocilloporid, massive, and nodular coral species. Reefs in Panamá conform to this pattern. However, on reefs of Colombia and Galápagos, non-pocilloporid corals, mainly pavonids, have a higher relative abundance than pocilloporids (Glynn et al. 1982, Glynn \& Wellington 1983). At Caño and Cocos Islands in Costa Rica, the main reef-builder is a single massive species, Porites lobata, which predominates (percent cover) on both the intertidal and deep reef. Prior to the 1985 red-tide mortality, pocilloporids predominated in the reef flat areas (Guzmán 1986, Guzmán. \& Cortés 1989).

Abundance of puffers and corals. In the present study, the abundances of corals and puffers were determined after the mass coral mortality We rely on previously published reports for pre-mortality conditions (e.g. Glynn et al. 1972, 1982, Glynn \& Wellington 1983, Glynn 1984, 1985).
We censused Arothron meleagris at Caño (East and North reefs), Cocos (Punta Pacheco) and Gorgona (Azufrada) Islands using belt transects ( 4 to $10 \mathrm{~m}$ wide) that extended along the depth gradient $(0.5$ to $15 \mathrm{~m})$. Total length of the transects were $2100 \mathrm{~m}$ (1985) and $1060 \mathrm{~m}(1986 / 87)$ at Caño Island, $1175 \mathrm{~m}$ at Cocos Island and $4800 \mathrm{~m}$ at Gorgona Island. At Uva and Secas, total counts were made by swimming in a zigzag path across the entire reef. Due to the sedentary nature of this fish, individuals probably were not counted more than once by the latter method. Censuses of entire reefs also were made at 5 of the Pearl Islands (Señorita, Saboga, Pacheca, Chapera and Contadora Islands) in the Gulf of Panamá, and at Santa Cruz Island (Baltra Canal, Punta Estrada and Coamaño Island), Galápagos.

In the 1984-1987 surveys at Caño Island, the percent of subtratum covered by live coral was estimated in 8 permanent $10 \mathrm{~m}^{2}$ quadrats on the east and north sides of the island. These were spread across the reef from the intertidal reef flat to lower limits of live coral accumulation. In 1980 and 1984, coral abundances were estimated on the east and north sides of the island by Guzmán et al. (1987), who used line (10 $\mathrm{m}$ long) and belt $(50 \times 1 \mathrm{~m})$ transects $(n=4$; total $40 \mathrm{~m}$ for 1980 ; and $n=8$; total $400 \mathrm{~m}$ for 1984 ) run perpendicular to the shore. Line transects were used at Cocos Island ( $n=$ 147; total $1470 \mathrm{~m}$, parallel to the shore), at Uva and Secas Islands $(n=13,850 \mathrm{~m}$, and $n=14,1396 \mathrm{~m}$ respectively, perpendicular to the shore), and at the Pearl Islands $(n=20,200 \mathrm{~m}$ at each site, perpendicular to the shore). On the Uva Island rocky shore we measured the diameter of all coral colonies in seven areas ranging from 150 to $350 \mathrm{~m}^{2}$ (total $2506 \mathrm{~m}^{2}$ ).

Gut content analyses. Arothron meleagris feeds by breaking off pieces of corals and other organisms with its powerful beak, and ingesting these pieces whole (Glynn et al. 1972). We analyzed the gut contents of puffers that we speared at 4 sites: Caño Island, Cocos Island, Uva and Secas Islands. One set of individuals from Caño Island was taken 1 mo after the last of a series of red tides that occurred over a 3 mo period, and another set 1 to 2 yr later. Fish were collected at Uva and Secas Island reefs 3.5 and 5 yr after the El Niño event (i.e. ca 2.5 yr after the red tides). Fish were obtained at Cocos Island 4 and $5 \mathrm{yr}$ after the El Niño event. The fish ranged from 152 to $281 \mathrm{~mm}$ standard length (mean $170 \mathrm{~mm}$ ). Stomach contents were extracted within 1 h of collection and stored in ethanol. Contents were ovendried $\left(65^{\circ}\right.$ to $\left.80^{\circ} \mathrm{C}\right)$ to a constant weight. All contents (dried) were sorted to identifiable taxonomic groups under a dissecting microscope, and the percentage by weight of dry material in each group was recorded.

Growth on algal and coral diets. Thirty-one Arothron meleagris of similar size were captured from 
reefs around Caño Island in August 1986 and starved for 24 to $30 \mathrm{~h}$. Each individual was tagged (using injectable plastic clothing tags inserted under the skin at the base of different fins), and its weight (determined using a small spring balance inserted in the angle of the operculum) and standard length were recorded. Fifteen randomly chosen individuals were set free, and 2 groups of 8 fish each were kept in separate cages, each $1.6 \times 0.7 \times 0.7 \mathrm{~m}$, placed at $2 \mathrm{~m}$ depth in a protected lagoon. One captive group (live coral diet) was fed exclusively Pocillopora damicornis (Linnaeus) and Porites lobata Dana in excess of demand. The other captive group (algal diet) was fed only crustose coralline algae, mainly Porolithon castellanum Dawson, Porolithon oncodes Fosline and Sporolithon pacificum Dawson on coral rocks. Other marine organisms known to be eaten by $A$. meleagris (e.g. crabs, worms, sponges, brittle stars) were removed from corals and algae prior to their introduction into the cages. The food in all cages was renewed weekly. After $108 \mathrm{~d}, 7$ individuals from each treatment were starved for $30 \mathrm{~h}$, then their weights and lengths were recorded.

Prey choice experiments. At Caño Island, fish were maintained in $490 \mathrm{l}$ plastic tanks supplied with continuously running, aerated seawater. At Uva Island, fish were kept in $1 \mathrm{~m}^{3}$ wire mesh cages attached to the reef framework. Pocillopora damicornis, Porites lobata and Psammocora stellata were used in feeding experiments at both localities.

At Caño Island, fish were fed 7 diets that differed in the relative proportions of 3 corals, or of corals and crustose coralline algae (CCA): (1) $25 \%$ Porites $+75 \%$ Pocillopora; (2) $50 \%$ Porites $+50 \%$ Pocillopora; (3) $75 \%$ Porites $+25 \%$ Pocillopora; (4) $5 \%$ coral (Pocillopora or Porites or Psammocora, each separately) with $95 \% \mathrm{CCA}_{\text {; }}$ (5) $25 \%$ coral (same set of species) with $75 \% \mathrm{CCA}_{\text {; }}$ (6) $50 \%$ Pocillopora with $50 \% \mathrm{CCA}$; and (7) $75 \%$ Pocillopora with $25 \%$ CCA. Six fish (replicates) were separately offered each diet for $3 \mathrm{~d}$. A different fish was used in each case. Whole coral colonies with a minimum diameter of 25 to $30 \mathrm{~cm}$ were used in all experiments. At Uva Island, 2 prey choices were used: (1) $50 \%$ Pocillopora $+50 \%$ Porites, and (2) $50 \%$ Pocillopora $+50 \%$ Psammocora. Ten different fish in separate cages were used for each treatment, which ran concurrently for 7 consecutive days.

We assessed preference in terms of decrease in weight of coral colonies and algae offered to the puffers. Factorial ANOVA and t-tests were used to analyze the data. Assumptions of these procedures were tested, and when necessary, percentage data were analyzed after arcsine transformation (Schefler 1980).

\section{RESULTS}

\section{Changes in coral communities due to mass mortality}

At Caño Island coral cover was low prior to the El Niño mortality, and Porites lobata was 3.4 times more abundant than Pocillopora spp. The El Niño affected Porites more severely than Pocillopora and these 2 corals became about equally abundant. The 1985 red tides greatly reduced the abundance of Pocillopora but had little effect on Porites, and Pocillopora became much less abundant than Porites (Table 1).

On reefs in the Gulf of Chiriquí coral cover was moderate to high prior to the El Niño mortality (Table 2), and Pocillopora was by far the most abundant coral (Table 3). Although the mortality reduced live coral cover by $50 \%$ (Glynn 1985), the relative predominance of Pocillopora remained unchanged. Currently, on the Gulf of Chiriquí reefs, Pocillopora is 70 to 150 times more abundant than at Caño Island, and Porites is 2 to $26 \%$ as abundant as at Caño. Psammocora was and is rare at all sites, but is more abundant on Gulf of Chiriquí reefs than on the Costa Rican reefs (Table 3 ).

Table 1 Estimated changes in the coral community at Caño Island following the El Niño (1982-83) and Red tide (1985) coral mortalities. Sources: Guzmán et al. (1987) for 1980-1984 data; present study for 1985-1987 data

\begin{tabular}{|c|c|c|c|c|}
\hline Date & $\begin{array}{l}\text { Total }^{\mathrm{a}} \\
\text { absolute }\end{array}$ & $\begin{array}{c}\text { Porites } \\
\text { Absolute/Relative (\% change) }\end{array}$ & $\begin{array}{l}\text { Percent abundance of corals }{ }^{\mathrm{b}} \\
\text { Pocillopora } \\
\text { Absolute/Relative (\% change) }\end{array}$ & $\begin{array}{c}\text { Psammocora } \\
\text { Absolute/Relative ( } \% \text { change) }\end{array}$ \\
\hline 1980 & 17.8 & $11.8 / 66.2$ & $3.5 / 19.4$ & $0.9 / 4.9-$ \\
\hline 1984 & 6.5 & $3.4 / 53.0(-70.9)$ & $2.8 / 43.4(-18.6)$ & $0.0 / 0.0(0.0)$ \\
\hline 1985 & 3.8 & $3.4 / 90.4 \quad(-1.0)$ & $0.2 / 5.1(-93.3)$ & $0.0 / 0.0(0.0)$ \\
\hline $1986 / 87$ & 4.3 & $3.7 / 85.7(+6.6)$ & $0.3 / 8.0(+80.0)$ & $0.5 / 1.2(+>100)$ \\
\hline \multicolumn{5}{|c|}{$\begin{array}{l}\text { ancludes all coral species } \\
\text { Absolute }=\% \text { of total substratum. Relative }=\% \text { of coral coverage. } \% \text { change }=\% \text { change in absolute abundance fror } \\
\text { previous census }\end{array}$} \\
\hline
\end{tabular}


Table 2. Abundance of corals and Arothron meleagris on eastern Pacific reefs before and after the El Nino (1982-1983) and redtide (1985) coral mortalities

\begin{tabular}{|c|c|c|c|c|c|c|c|c|}
\hline \multirow[t]{2}{*}{ Site } & \multicolumn{4}{|c|}{ Coral abundance } & \multicolumn{3}{|c|}{ Puffer abundance } & \multirow[t]{2}{*}{ Source } \\
\hline & $\begin{array}{l}\text { Census } \\
\text { date }\end{array}$ & $\begin{array}{l}\text { Total } \\
\text { reef } \\
\text { area } \\
\text { (ha) }\end{array}$ & $\begin{array}{l}\text { Total area } \\
\text { live coral } \\
\text { (ha) }\end{array}$ & $\begin{array}{l}\text { Live } \\
\text { coral } \\
\text { cover } \\
(\%)\end{array}$ & $\begin{array}{c}\text { Overall } \\
\text { density } \\
\text { (ind. } \mathrm{ha}^{-1} \text { ) }\end{array}$ & $\begin{array}{l}\text { Density of } \\
\text { Live coral } \\
\text { (ind. ha }{ }^{-1} \text { ) }\end{array}$ & $\begin{array}{l}\text { No. of } \\
\text { transects }\end{array}$ & \\
\hline \multicolumn{9}{|l|}{ COSTA RICA } \\
\hline Caño Is. reef & $\begin{array}{l}1985 \\
1986 / 87\end{array}$ & $\begin{array}{l}16 \\
16\end{array}$ & $\begin{array}{l}0.62 \\
0.69\end{array}$ & $\begin{array}{l}3.8 \\
4.3\end{array}$ & $\begin{array}{r}5 \\
11\end{array}$ & $\begin{array}{l}129 \\
255\end{array}$ & $\begin{array}{r}13 \\
3\end{array}$ & $\begin{array}{l}\text { Guzmán (1986) } \\
\text { Present study }\end{array}$ \\
\hline $\begin{array}{l}\text { Cocos Is. } \\
\text { (Pacheco reef) }\end{array}$ & 1987 & 4 & 0.10 & 2.6 & 8 & 320 & 5 & Present study \\
\hline \multicolumn{9}{|l|}{$\begin{array}{l}\text { PANAMA } \\
\text { Gulf of Chiriqui }\end{array}$} \\
\hline Uva Is. reef & $\begin{array}{l}1981 \\
1986 / 88\end{array}$ & $\begin{array}{l}2.4 \\
2.4\end{array}$ & $\begin{array}{l}1.08 \\
0.68\end{array}$ & $\begin{array}{l}45.0 \\
28.2\end{array}$ & $\begin{array}{l}50 \\
55\end{array}$ & $\begin{array}{l}111 \\
194\end{array}$ & $\begin{array}{r}22 \\
4\end{array}$ & $\begin{array}{l}\text { Glynn (1985) } \\
\text { Present study }\end{array}$ \\
\hline Uva rocky habitat & $1986 / 88$ & 1.05 & 0.0034 & 0.2 & 19 & 6650 & 7 & Present study \\
\hline Secas Is reef & $\begin{array}{l}1976 \\
1986 / 88\end{array}$ & $\begin{array}{l}7.6 \\
7.6\end{array}$ & $\begin{array}{l}1.25 \\
1.05\end{array}$ & $\begin{array}{l}16.5 \\
13.8\end{array}$ & $\begin{array}{l}\text { ND } \\
27\end{array}$ & $\begin{array}{l}\text { ND } \\
195\end{array}$ & $\begin{array}{l}0 \\
5\end{array}$ & $\begin{array}{l}\text { Glynn (1984) } \\
\text { Present study }\end{array}$ \\
\hline \multicolumn{9}{|l|}{ Gulf of Panamá } \\
\hline Señorita Is. & $\begin{array}{l}1971 \\
1987\end{array}$ & $\begin{array}{l}0.8 \\
0.8\end{array}$ & $\begin{array}{l}0.60 \\
0.40\end{array}$ & $\begin{array}{l}75.0 \\
49.5\end{array}$ & $\begin{array}{r}40 \\
0\end{array}$ & $\begin{array}{r}53 \\
0\end{array}$ & $\begin{array}{l}1 \\
5\end{array}$ & $\begin{array}{l}\text { Glynn et al. (1972) } \\
\text { Present study }\end{array}$ \\
\hline Saboga Is. & 1987 & 14.3 & 5.65 & 39.5 & 0 & 0 & 6 & Present study \\
\hline Pacheca Is. & 1987 & 3.1 & 0.03 & $\sim 1$ & 0 & 0 & 3 & Present study \\
\hline Chapera Is. & 1987 & 6.8 & 0.34 & $\sim 5$ & 0 & 0 & 3 & Present study \\
\hline \multicolumn{9}{|l|}{ COLOMBIA } \\
\hline Gorgona Is. & $\begin{array}{l}1979 \\
1987 / 88\end{array}$ & $\begin{array}{l}15 \\
15\end{array}$ & $\begin{array}{l}5.4 \\
7.3\end{array}$ & $\begin{array}{l}36 \\
48.5\end{array}$ & $\begin{array}{l}12 \\
34\end{array}$ & $\begin{array}{l}33 \\
71\end{array}$ & $\begin{array}{r}9 \\
12\end{array}$ & $\begin{array}{l}\text { Glynn et al. (1982) } \\
\text { Prahl \& Lopez } \\
\text { pers. comm. }\end{array}$ \\
\hline \multicolumn{9}{|c|}{ ECUADOR (Galápagos) } \\
\hline San Cristobal Is. & 1976 & -4 & $\sim 0.6$ & 15 & 2 & $\sim 13^{a}$ & 3 & $\begin{array}{l}\text { Glynn \& Welling- } \\
\text { ton (1983) }\end{array}$ \\
\hline Santa Cruz Is. & 1986 & -1 & $\sim 0.01$ & $\sim 1$ & 0.01 & $\sim 1^{a}$ & 2 & $\begin{array}{l}\text { Glynn pers. } \\
\text { comm, present } \\
\text { study }\end{array}$ \\
\hline $\begin{array}{l}\text { ND: no data availat } \\
{ }^{a} \text { Original census da } \\
\text { which we surveye }\end{array}$ & fish per & man-h & were tra & ormed & nd. $h a^{-1}, a$ & ming a su & rate of & ha h$h^{-1}$ (i.e. rate at \\
\hline
\end{tabular}

Table 3. Abundance of 3 corals at 4 eastern Pacific reefs in 1986/88. Absolute abundance $=\%$ of substratum covered by the coral; relative abundance $=\%$ of coral coverage represented by that species, or genus

\begin{tabular}{|c|c|c|c|c|c|c|}
\hline \multirow[t]{2}{*}{ Site } & Por & \multicolumn{4}{|c|}{ Percent abundance } & ora \\
\hline & Absolute & Relative & Absolute & Relative & Absolute & Relative \\
\hline Caño Is. & 3.66 & 90.3 & 0.34 & 8.4 & 0.05 & 1.3 \\
\hline Cocos Is. & 3.62 & 90.5 & 0.16 & 4.0 & 0.22 & 5.5 \\
\hline Secas Is. & 0.07 & 0.5 & 13.19 & 95.7 & 0.52 & 3.8 \\
\hline Uva Is. & 1.04 & 3.7 & 26.70 & 94.7 & 0.45 & 1.6 \\
\hline
\end{tabular}




\section{Abundance of puffers}

The densities of Arothron meleagris prior to the coral mortalities at 4 sites are known: Uva and Señorita Islands (Panamá; Glynn et al. 1972), Gorgona Island (Colombia; Glynn et al. 1982), and San Cristobal Island (Galápagos; Glynn \& Wellington 1983). At Uva Island A. meleagris was very abundant before the coral mortality. Some 4 to $5 y \mathrm{r}$ after the El Niño coral mortality, when coral cover was about 1/3 lower, the overall density of the puffer was about the same but its density relative to the abundance of corals had increased by $75 \%$ (Table 2). At Senorita Island puffers were common 11 yr before the El Niño mortality, while 4.5 yr after the El Niño event they were absent. Coral mortality was about the same at Senorita and Uva Islands, and the total abundance of live coral at Senorita Island was $60 \%$ of that at Uva Island (Table 2). At Gorgona Island (Colombia) live coral cover was about $35 \%$ greater 4 to 5 yr after than 6 to 7 yr before the El Nino event and the density of the puffer was about 2 to 3 times higher after the El Niño event than before (Table 2). No information is available on the status of the population of $A$ meleagris at San Cristobal after the El Niño event

Puffer abundances varied among sites and time periods. Before the El Niño event, puffer densities on coral reefs varied from 2 to 50 fish ha ${ }^{-1}$ of reef and 13 to 111 fish ha ${ }^{-1}$ of live coral. In 1986 to 1988 abundances ranged from 0 to 55 fish $\mathrm{ha}^{-1}$ of total substratum and from 0 to 320 fish $\mathrm{ha}^{-1}$ of live coral on reefs (and to over 6000 fish $\mathrm{ha}^{-1}$ of live coral on a rocky shore) (Table 2).

In 1986 to 1988 , several years after the coral mortality, variation in total size of populations of Arothron meleagris was positively, but weakly, correlated with variation in both total reef area and total coral area on reefs (Pearson's $r_{(12)}=0.60$ and 0.61 , respectively, both $p<0.05)$. However, variation in the density of the puffer (fish ha ${ }^{-1}$ ) on different reefs was not correlated with variation in either abundance of corals (percent cover), total coral area per reef or total reef area $\left(r_{(12)}=\right.$ $0.34,0.25,0.10$, respectively, all $p>0.05$; Table 2$)$.

\section{Diet of Arothron meleagris}

\section{Changes following coral mortality}

Arothron meleagris captured at Caño Island 1 mo after the red-tide mass coral mortality had eaten principally crustose coralline algae and Psammocora, but little Porites (Table 4). Individuals captured 1 to $2 \mathrm{yr}$ later had a different diet (ANOVA, $F=12.10, p<0.01$ ), due mainly to a large increase in the consumption of Porites lobata (Tables 4 and 5). In 4 other cases (2 in Costa Rica and 2 in Panamá Table 4) the post-mortality diets of fish collected from the same site at 1 to $2 y \mathrm{r}$ intervals (both after the coral mortality) did not differ. Although fish collected at Cocos Island during December 1986 and 1987 had eaten mainly Porites lobata, their diet differed from that of fish collected at Caño Island during the same years (Table 4 ; ANOVA, $F=7.01, p<0.01$ ). This difference mainly was due to heavy consumption of coralline algae and Psammocora at Caño Island and of the echinoid Tripneustes depressus at Cocos Island (Table 4).

In the Gulf of Chiriquí, pocilloporid corals comprised almost the entire diet of fish collected on reefs both before the 1982-1983 coral mortality and 5 yr afterwards (Table 4), and were the major item eaten by fish on rocky habitat adjacent to Uva reef. The coral diets of fish from Uva (before and after the coral mortality) and Secas reefs did not differ, but both differed from the coral diet of fish collected from the Uva rocky habitat (ANOVA, $F=16.12, p<0.01$; and Student-NewmanKeuls [SNK] Multiple Comparisons at $p=0.01$ ). Fish on the rocky shore had a more varied diet than fish on those 2 reefs (Table 4 ).

Individual ANOVA tests performed to compare differences in the amount of any item in the diet of Arothron meleagris at Uva and Secas, Cocos and Caño Islands after the coral mortalities detected significant differences $(p<0.001)$ for all coral species, coralline algae and remaining food items (pooled), but no difference $(p>0.05)$ for the hydrocoral Millepora spp. SNK Multiple Comparison tests showed differences in the consumption of Pocillopora and Porites at Caño and Cocos reefs, Uva and Secas reef and the Uva rocky habitat. Consumption of Psammocora differed between each of the reefs (Cocos, Caño, and Uva) and Secas reef. Fish at various sites differed in terms of consumption of coralline algae, and of other diet items (Table 4).

\section{Consumption of corals in relation to availability}

At reefs at Caño, Cocos, Secas and Uva Islands, and the rocky shore at Uva, the proportion of corals (all species combined) in the fish's diet was greater than expected from the percent of substratum covered by corals (Wilcoxon Sign Rank Test, $Z=2.02, p<0.05$ ).

Among the Gulf of Chiriquí sites, coral community composition (i.e percent cover of different corals) on the Uva rocky shore was different than on the Uva and Secas reefs (Table 5, ANOVA, $F=16.13, p<0.01$, SNK Multiple Comparison Test, $p<0.01$ ). Fish collected at each of these 3 sites consumed Porites, Pocillopora and Psammocora in relation to their abundances at each site (Table 5)

At Caño Island, where it was rarer than at Cocos and the Gulf of Chiriquí reefs (Table 3), Psammocora was 


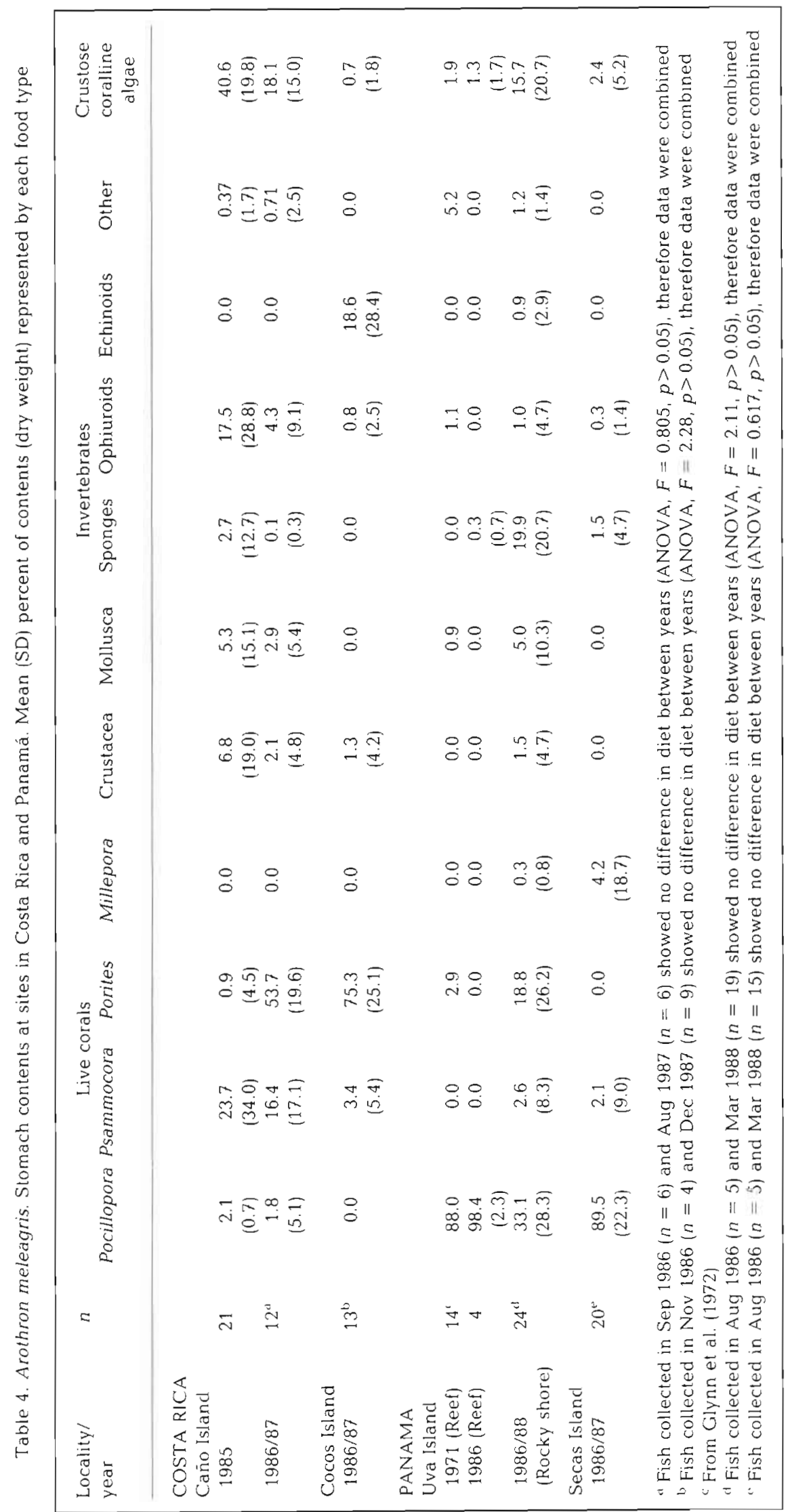


Table 5. Relative abundance of different corals in the field and in the diets of Arothron meleagris at 5 eastern Pacific sites. Mean (SD); Student's $t$-test on means, $\mathrm{ns}=p>0.05,{ }^{*} p<0.05, \cdots p<0.01$

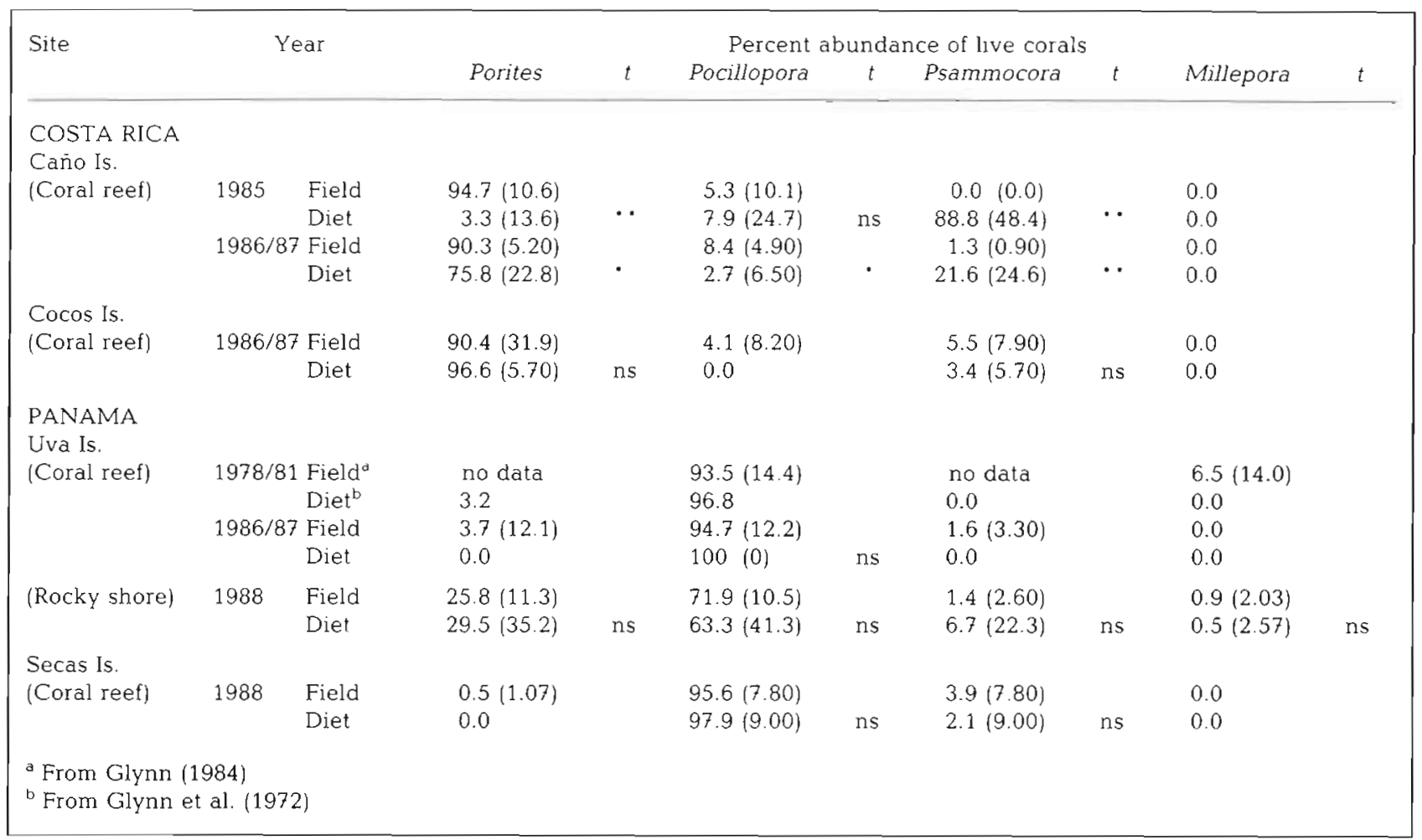

an important item in the diet of fish collected immediately after the red tide and 1 to 2 yr later: and was consumed much more than expected on the basis of its availability (Table 5). Immediately after the red tide, fish at Caño Island ate Porites much less than expected. Although Porites had become the major diet item 1 to 2 yr later, it was consumed less than expected due to its availability. Immediately after the red tides, Pocillopora was consumed in relation to its availability, while 1 to 2 yr later it was consumed less than expected (Table 5).
Prey selection experiments

Puffers at Caño Island in 1986 preferred corals, even when they were uncommon. However, they also included algae in their diets even when algae were less abundant than corals, and algae constituted ca 25 to $35 \%$ of the diet in most experiments involving choices with different corals (Table 6).

Puffers at Caño Island preferred Porites lobata regardless of whether it was more or less abundant than $P$.

Table 6. Arothron meleagris. Consumption of 3 corals and crustose coralline algae (CCA) in paired choice experiments at Cano Island in 1986. Mean (SD) percent of material (by weight) eaten that was coral or coralline algae. Student's $t$-test using arcsinetransformed data; $\cdots p<0.01 ; n=6$ in each case

\begin{tabular}{|c|c|c|c|c|c|c|c|c|c|}
\hline $\begin{array}{l}\% \text { Coral/CCA } \\
\text { in material } \\
\text { offered }\end{array}$ & Pocillopora ${ }^{a}$ & $\mathrm{CCA}$ & $t$ & Porites ${ }^{b}$ & $\mathrm{CCA}$ & $t$ & Psammocora ${ }^{c}$ & $\mathrm{CCA}$ & $t$ \\
\hline $5 / 95$ & $73.8(16.6)$ & $26.2(11.7)$ & $10.5^{\cdots}$ & $62.9(18.9)$ & $37.1(13.7)$ & $5.3^{\cdots}$ & $62.5(9.44)$ & $37.5(8.73)$ & $6.0^{\circ}$ \\
\hline $25 / 75$ & $70.8(16.7)$ & $29.2(13.1)$ & $8.9 \cdot$ & $69.8(18.7)$ & $30.2(7.78)$ & $8.8^{\cdots}$ & $73.4(3.18)$ & $26.6(5.91)$ & $13.9^{\cdots}$ \\
\hline $50 / 50$ & $76.3(14.9)$ & $23.7(15.3)$ & $11.5^{\cdots}$ & & no data & & & no data & \\
\hline $75 / 25$ & $83.1(6.91)$ & $16.9(7.94)$ & $18.1^{\cdots}$ & & no data & & & no data & \\
\hline \multicolumn{10}{|c|}{${ }^{2}$ Consumption of Pocillopora at different abundances (ANOVA, $F=0.63, p>0.05$ ) } \\
\hline \multicolumn{10}{|c|}{${ }^{\mathrm{b}}$ Consumption of Porites at different abundances (Student's $t, t=0.63, p>0.05$ ) } \\
\hline \multicolumn{10}{|c|}{ c Consumption of Psammocora at different abundances (Student's $t, t=2.68, p<0.05$ ) } \\
\hline
\end{tabular}


Table 7. Arothron meleagris. Consumption of Porites lobata and Pocillopora damicornis, in paired choice experments at Cano Island in 1986. Mean (SD) percent by weight of corals eaten. Student's $t$-test using arcsine-transformed data, $\cdots p<0.01$

\begin{tabular}{|llllr|}
\hline $\begin{array}{l}\text { ". Porites' } \\
\text { Pocillopora in } \\
\text { coral offered }\end{array}$ & Porites & Pocillopora & $n$ & $t$ \\
\hline $25 / 75$ & $71.8(6.71)$ & $28.2(4.96)$ & 6 & $12.5 \cdots$ \\
$50 / 50$ & $68.0(14.4)$ & $32.0(13.1)$ & 6 & $7.8 \cdots$ \\
$75 / 25$ & $93.1(5.17)$ & $6.90(4.93)$ & 6 & $28.3 \cdots$ \\
\\
a Consumption of Porites at different abundances \\
(ANOVA, F=5.73,p<0.01) \\
\hline
\end{tabular}

damicornis (Table 7). At Panamá, puffers showed no preference between the same 2 species of corals when given a 50:50 choice, but showed a distinct preference for Pocillopora over Psammocora (Table 8).

\section{Growth on different diets}

Arothron meleagris fed for 108 d on different diets showed significant differences in weight gain (Table 9). A posteriori ( $\mathrm{SNK}$ ) testing shows that free-ranging puffers and those fed corals gained more weight than fish fed coralline algae, but that fish fed corals and free- ranging fish did not differ. The increase in length of fish fed different diets did not differ (Table 9).

\section{DISCUSSION}

\section{Variation in abundance of puffers}

Both strong and weak positive correlations with much variability have been observed between abundances of corals and corallivorous chaetodontid fishes at various Indo-Pacific reefs (Reese 1977, Bell \& Galzin 1984, Bell et al. 1985, Bouchon-Navaro et al. 1985 , Roberts \& Ormond 1987). Arothron meleagris may occur most commonly on coral reefs because a diet consisting primarily of corals is best for its growth, although it can maintain growth on a diet consisting entirely of algae. However, neither the upper nor the lower limits of puffer density on eastern Pacific reefs are set by coral availability. Although larger reefs tend to have larger puffer populations, puffer density is unrelated to coral density and the fish is absent on some large reefs where its food corals are abundant and its diet requirements should be met. It can also be abundant on rocky shores and maintain a diet including much live coral even though coral density is low. Even when most abundant, this puffer may be only a minor consumer of corals. Present annual consumption

Table 8. Arothron meleagris. Consumption of 3 corals in paired choice experiments (50:50 offering) at Uva Island in 1988. Mean (SD) percent by weight of coral eaten

\begin{tabular}{|c|c|c|c|c|c|c|c|}
\hline Pocillopora & Porites & $n$ & $t^{\mathrm{d}}$ & Pocillopora & Psammocora & $n$ & $t^{\mathrm{d}}$ \\
\hline $\begin{array}{c}52.8 \\
(39.1)\end{array}$ & $\begin{array}{l}47.2 \\
(38.5)\end{array}$ & 8 & $\begin{array}{c}0.33 \\
p>0.05\end{array}$ & $\begin{array}{c}82.1 \\
(31.5)\end{array}$ & $\begin{array}{c}17.9 \\
(31.3)\end{array}$ & 9 & $\begin{array}{c}14.5 \\
p<0.01\end{array}$ \\
\hline
\end{tabular}

Table 9. Arothron meleagris. Changes in weight and length of pufferfish exposed to 3 diet regimes for 108 d at Caño Island Mean (SD)

\begin{tabular}{|c|c|c|c|c|c|c|c|}
\hline \multirow{2}{*}{$\begin{array}{l}\text { Diet } \\
\text { treatment }\end{array}$} & \multirow[t]{2}{*}{$n$} & \multicolumn{2}{|c|}{ Inttial } & \multicolumn{2}{|c|}{ Final } & \multicolumn{2}{|c|}{ Mean $\%$ increase } \\
\hline & & Weight $(\mathrm{g})$ & Length (mm) & Weight (g) & Length (mm) & Weight & Length ${ }^{b}$ \\
\hline Live coral & 7 & $\begin{array}{c}164 \\
(30.1)\end{array}$ & $\begin{array}{c}230 \\
(10.1)\end{array}$ & $\begin{array}{c}176 \\
(28.9)\end{array}$ & $\begin{array}{c}240 \\
(13.1)\end{array}$ & $\begin{array}{l}11.6 \\
(2.51)\end{array}$ & $\begin{array}{l}10 \\
(3.70)\end{array}$ \\
\hline Coralline algae & 7 & $\begin{array}{c}138 \\
(34.3)\end{array}$ & $\begin{array}{c}240 \\
(18.5)\end{array}$ & $\begin{array}{c}141 \\
(33.9)\end{array}$ & $\begin{array}{c}244 \\
(16.7)\end{array}$ & $\begin{array}{c}3.9 \\
(2.04)\end{array}$ & $\begin{array}{c}5.4 \\
(2.70)\end{array}$ \\
\hline Control & 7 & $\begin{array}{c}147 \\
(28.4)\end{array}$ & $\begin{array}{c}218 \\
(22.5)\end{array}$ & $\begin{array}{c}158 \\
(28.3)\end{array}$ & $\begin{array}{c}226 \\
(22.8)\end{array}$ & $\begin{array}{l}10.6 \\
(1.62)\end{array}$ & $\begin{array}{c}7.6 \\
(3.64)\end{array}$ \\
\hline \multicolumn{8}{|c|}{$\begin{array}{l}{ }^{a} \text { Covariance Analysis, } F=28.2 . p<0.001 \\
{ }^{b} \text { Covariance }\end{array}$} \\
\hline
\end{tabular}


of coral by the high density population of $A$. meleagris at Uva reef is only $0.3 \%$ of the total coral standing crop, and the reef is showing net growth (Glynn 1985). Substantial changes in coral abundance on some reefs with dense puffer populations have not been accompanied by patterns of change in those populations expected if coral abundance is directly controlling fish abundance.

The eastern Pacific study reefs vary not only in the absolute and relative abundance of various species of corals, but also in the topography of the habitat, and exposure of the reef to physical stresses (Glynn \& Wellington 1983). Although such factors influence reef fish populations (Hiatt \& Strasburg 1960, Randall 1963, Anderson et al. 1981, Sano et al. 1984), variation in recruitment of planktonic juveniles of reef fishes may independently exert strong influences on reef fish populations (e.g. Munro \& Williams 1985, Victor 1986, Doherty \& Williams 1988). Wellington \& Victor (1985) found that the population of a damselfish that establishes feeding territories on dead coral substrata did not increase on a Pearl Island reef following the mass coral mortality of 1982-1983. They concluded that this population was recruitment limited rather than resource limited. The patterns of both variation in density of Arothron meleagris among eastern Pacific reefs and of change in several populations following mass coral mortalities that we have described here are not related to resource abundance. They could be due to its populations being controlled by juvenile recruitment.

Two studies of responses of reef fishes to coral mortality in the Western Pacific (Sano et al. 1984, Williams 1986) found that populations of corallivorous fishes declined sharply after the coral mortality. Differences between the results of those studies and the present one probably reflect a combination of factors: the extent to which fish populations were determined by pre-mortality coral abundances, the level of coral mortality, and the ability of fishes to switch diets and survive and grow on non-coral diets.

\section{Diet of Arothron meleagris in relation to food availability}

The diet of a fish may be influenced by the availability of food types and the flexibility of its feeding preferences. As the abundance of a prey changes, predation pressure on the prey population may increase or decrease. Recovery of a prey population from heavy mortality may be influenced by population and dietary responses of its predators to that initial prey decline.

The diet of Arothron meleagris at Caño Island was different 1 mo after the red-tide coral mortality and 1 to 2 yr later. This difference is not a sampling artifact. This was the only one of 5 cases we examined in which 2 diet samples taken from a single population at intervals of a year or more differed, and the first sample was taken immediately after a mass mortality of corals. The 1985 red tides at Caño Island principally affected Pocillopora, reducing it from being about equal in abundance with Porites, to near absence. A. meleagris probably fed heavily on pocilloporid corals prior to that mortality since they were the most abundant corals in shallow water. Following this sharp decline of the relatively abundant pocilloporids, the puffers shifted first to crustose coralline algae, an abundant, low quality food. The puffer then switched to a more nutritious diet consisting mainly of the most abundant remaining coral (Porites) and subsequently developed a feeding preference for that coral.

The differences in the puffer's relative preference for Porites and Pocillopora at Caño Island and Uva Island correlate with the relative abundances of these 2 corals at the 2 sites. The fish may develop a preference for a particular, abundant species of coral (e.g. Porites lobata). However, since such a preference does not develop for any coral species simply because it is most abundant (e.g. Pocillopora damicornis at Uva reef), its feeding preference is only partly labile.

Although Arothron meleagris at Caño Island primarily ate the rare coral Psammocora, no such selective feeding on that coral was evident at either Cocos Island or on Panamanian reefs. Our experiments at Uva Island (Panamá) demonstrated a preference for Pocillopora over Psammocora. These differences in feeding on Psammocora among sites are not related to variation in the availability of Psammocora. Psammocora was rarest at the site at which it was most heavily fed upon (Caño Island). The difference in consumption of Psammocora at Panamá and Caño Island cannot be attributed to differences in absolute coral abundance, since total coral cover was as low at Cocos Island as at Caño Island. Differences in the accessibility of Psammocora may have permitted greater feeding at Caño Island, where colonies of Psammocora are exposed, than at Cocos Island, where they are in crevices. However, colonies of Psammocora are exposed and readily accessible at Uva and Secas Islands (Panamá), where this coral is rarely eaten.

At several sites non-coral items were conspicuous in the puffer's diet. At Caño Island algae were a substantial component of the diet even when fish were presented an excess of corals. At Uva and Secas reefs corals were the primary component of the diet, and algae were rarely eaten. These differences and those in the puffer's feeding responses on Porites and Pocillopora at different localities indicate that the feeding preferences of Arothron meleagris are complex and labile, and that preference is not the only factor determining its diet. 
Birkeland \& Neudecker (1981) found that a Caribbean chaetodontid that feeds on corals was an active generalist that, by feeding selectively, increased the evenness of its diet. In contrast, Tricas (1985) found that a Hawaiian corallivorous Chaetodon species narrowed its diet by selectively consuming the most abundant coral. With Arothron meleagris the situation is more complex and variable. At the Panamanian sites and at Cocos Island, $A$. meleagris behaved as a passive generalist, consuming corals in relation to their availability. At Caño Island it behaved as an active generalist (sensu Birkeland \& Neudecker 1981), broadening its diet by feeding selectively on the rarest coral; yet preferring the commonest coral (Porites) over a less common one (Pocillopora) there.

\section{Potential effects of Arothron meleagris on coral recovery}

Populations of Arothron meleagris survived major mortality of corals on eastern Pacific reefs. Although the diet of A. meleagris consists almost exclusively of Pocillopora at some sites, and this fish has been able to maintain its populations following mass coral mortality, the preference by the puffer for Porites over Pocillopora at Caño Island, the rarity of the latter in the puffer's diet there, and the puffer's apparent inertia to diet changes, should favor the re-establishment of Pocillopora there. Planktonic larvae of Pocillopora recruit at very low rates on some eastern Pacific reefs (Richmond 1985), including Caño Island (H. Guzmán unpubl.). Since this recruitment pattern will slow any initial recovery, changed feeding preferences of even a low density population of A. meleagris could be influential. On the other hand, $A$. meleagris could have a severe impact on the population of Psammocora at Caño Island, since that rare coral is selectively fed upon and is a major component in the puffer's diet. Thus the impact of A. meleagris on coral recovery is likely to be complex and changing, and to affect coral species differently at different sites. This impact may be substantial on uncommon prey species even when the puffer is not very abundant.

Acknowledgements. We thank the personnel of The Caño Island Biological Reserve, and the Marenco Biological Station, and the crew of the RV 'Benjamin' Juan D. Lopez and Henry von Prahl made the coral and puffer surveys at Gorgona Island (Colombia). F. Cortés from the National Park Services of Costa Rica and the Harbor Branch Oceanographic Foundation invited H.M.G. to participate in the RV Seward Johnson cruise to Galápagos and Cocos Island. Special thanks are given to P.W. Glynn for encouraging the project and discussions. Also, we thank J. Christy, J. Cortés, P. Gilynn and H. Lessios for their comments to the manuscript. Financial support came from the Smithsonian Tropical Research Institute Short-term Fellowship Program and the National Science Foundation (grant OCE-8415615 to P. W Glynn).

\section{LITERATURE CITED}

Anderson, G. R. V., Ehrlich, A. H., Ehrlich, P. R., Roughgarden, J. D., Russell, B. C., Talbot, F. H. (1981). The community structure of coral reef fishes. A.m. Nat. 117: 476-495

Bakus, G. J. (1975). Marine zonation and ecology of Cocos Island, off Central America. Atoll Res. Bull. 179: 1-9

Bell, J. D., Galzin, R. (1984). Influence of live coral cover on coral reef fish communities. Mar. Ecol. Prog. Ser 15: $265-274$

Bell, J. D., Harmelin-Vivien, M., Galzin, R. (1985). Large scale spatial variation in the abundance of butterflyfishes (Chaetodontidae) on Polynesian reefs. Proc. 5th int. coral Reef Congr., Tahiti 5: 421-426

Birkeland, C., Neudecker, S. (1981). Foraging behavior of two Caribbean chaetodontids: Chaetodon capistratus and $C$. aculeatus. Copeia 1981: 169-178

Bouchon-Navaro, $Y .$, Bouchon, C., Harmelin-Vivien, $M$. (1985). Impact of coral degradation on a chaetodontid fish assemblage (Moorea, French Polynesia). Proc. 5th int coral Reef Congr., Tahiti 5: 427-432

Doherty, P. J., Williams, D. McB. (1988). Replenishment of reef fish populations. Oceanogr. mar. Biol. A. Rev. 26: 487-551

Glynn, P. W (1976). Some physical and biological determinants of coral community structure in the eastern Pacific. Ecol. Monogr. 46: 431-456

Glynn, P. W (1984). Widespread coral mortality and the 1982-83 El Niño warming event. Environ. Conserv. 11 $133-146$

Glynn, P. W. (1985). Corallivore population sizes and feeding effects following El Niño (1982-1983) associated coral mortality in Panama. Proc. 5th int. coral Reef Congr., Tahiti 4: $183-188$

Glynn, P. W., Cortés, J., Guzmán, H. M., Richmond, R. H. (in press). El Niño (1982-83) associated coral mortality and relationship to sea surface temperature deviations in the tropical eastern Pacific. Proc. 6th int. coral Reef Symp.

Glynn, P. W., Prahl, H. von, Guhl, F. (1982). Coral reefs of Gorgona Island, Colombia, with special reference to corallivores and their influence on community structure and reef development. An. Inst. Invest. mar. Punta de Betin 12: $185-214$

Glynn, P. W., Stewart, R. H., McCosker, J. E. (1972). Pacific coral reefs of Panamá: structure, distribution and predators. Geol. Rdsch. 61. 483-519

Glynn, P. W., Wellington., G. M. (1983). Corals and coral reefs of the Galápagos Islands. Univ. of California Press, Berkeley

Guzmán, H. M. (1986). Estructura de la comunidad Arrecifal de la Isla del Caño, Costa Rica, y el efecto de perturbaciones naturales severas. M.S. thesis, Universidad de Costa Rica

Guzmán, H. M., Cortés, J. (1989). Coral reef structure at Caño Island, Pacific Costa Rica. P. S. Z. N. I. Mar. Ecol.10: 23-41

Guzmán, H M., Cortés, J., Richmond, R. H., Glynn, P. W (1987) Efectos de "El Niño-Oscilacion Sureña" 1982/1983 en los arrecifes coralinos de la Isla del Caño, Costa Rica. Rev. Biol. trop. 35: 325-332

Hiatt, R. W., Strasburg, D. W. (1960). Ecological relationships of the fish fauna on coral reefs of the Marshall Island. Ecol. Monogr. 30: 65-127

Hobson, E. S. (1974). Feeding relationships of teleostean fishes on coral reefs in Kona, Hawaii. Fish. Bull. U.S. 72: 915-1031

Munro, J. L., Williams, D. McB. (1985). Assessment and management of coral reef fisheries: biological, environmental and socio-economic aspects. Proc. 5th int. coral Reef Congr., Tahiti 4: 543-565 
Prahl, H. von (1985). Blanqueo masivo y muerte de corales hermatípicos en el Pacífico colombiano atribuídos al fenómeno del Niño 1982-83. Boletin ERFEN 12: 22-24

Randall, J. E. (1963). An analysis of the fish populations of artificial and natural reefs in the Virgin Islands. Carib. J. Sci. 3: $31-47$

Reese, E. S. (1977). Coevolution of corals and coral feeding fishes of the family Chaetodontidae. Proc. 3rd int. coral Reef Symp. 1 267-274

Richmond, R. H. (1985). Variations in the population biology of Pocillopora damicornis across the Pacific Ocean. Proc. 5th int. coral Reef Congr., Tahiti 6: 101-106

Roberts, C. M., Ormond, R. F. G. (1987). Habitat complexity and coral reef fish diversity and abundance on Red Sea fringing reefs. Mar. Ecol. Prog. Ser. 41: 1-8

Robinson, G. (1985). Influence of the 1982-83 El Niño on Galápagos marine life. In: Robinson, G., Pino, E. M. del (eds.) El Niño en las Islas Galápagos, El Evento de 1982-83. Fundación Charles Darwin para las Islas Galápagos, Quito, Ecuador, p. 153-190

Sano, M., Shimizu, M., Nose, Y. (1984). Changes in structure

This article was presented by Professor J. M. Lawrence,

Tampa, Florida, USA of coral reef fish communities by destruction of hermatypic corals: observational and experimental views. Pacif. Sci. 38: $51-79$

Schefler, W C. (1980). Statistics for the biological sciences. Addison-Wesley Publishing Co., London

Thomson, D. A., Findley, L. T., Kerstitch, A. N. (1979). Reef fishes of the Sea of Cortez. Wiley-Interscience Publication, John Wiley \& Sons, New York

Tricas, T. C. (1985). The economics of foraging in coralfeeding butterflyfishes of Hawaii. Proc. 5 th int. coral Reef Congr. 5: 409-414

Victor, B. C. (1986). Larval settlement and juvenile mortality on a recruitment-limited coral reef fish population. Ecol. Monogr 156: 145-160

Wellington, G. M., Victor, B. C. (1985). El Niño mass coral mortality a test of resource limitation in a coral reef damselfish population. Oecologia (Berl.) 68: 15-19

Williams, D. McB. (1986). Temporal variation in the structure of reef slope fish communities (Central Great Barrier Reef): short-term effects of Acanthaster planci infestation. Mar. Ecol. Prog. Ser. 28: 157-164

Manuscript first received: December 20, 1988

Revised version accepted: May 8, 1989 